\title{
Strategies and tactics of verbal countermanipulation
}

\author{
Marina V. Petrova
}

DOI: 10.18355/XL.2018.11.03.18

\begin{abstract}
The paper investigates two strategies and four tactics of verbal countermanipulation in Russian language discourse with the help of discourse analysis. The author provides a definition of the term "countermanipulation" and the description of linguistic characteristics of two strategies and four tactics of countermanipulation based on the analysis of the material taken from various sources (TV debates, radio discussions, etc.). The results show that verbal countermanipulation and its strategies and tactics need to be further examined on a deeper linguistic level with analysis of a larger amount of language material.
\end{abstract}

Key words: verbal countermanipulation, defence against manipulation, strategy, tactic, discourse analysis

\section{Introduction}

The purpose of this paper is to provide a linguistic analysis for two strategies (the overt and the covert strategy), and four tactics (tactic of revealing manipulation technique, flat refusal tactic, broken record tactic and clarification tactic) of verbal countermanipulation in Russian language discourse with the help of the method of discourse analysis (as it is described by Potter and Wetherell (1987)).

The concept of manipulation has been studied in various research fields, such as psychology, sociology, politology, social philosophy, linguistics, etc. (as discussed by Goodin, 1980; Lentz, 1989; Menz, 1989; Buss, 1992; Kopnina, 2008; Barnhill, 2014, etc.). The "response action to manipulation" (namely countermanipulation) has been given a scientific attention mainly in psychological works (Nazare-Aga, 2004; Braiker, 2004; Edmüller, Wilhelm, 2006; Simon, 2010; Edmüller et al. 2012; Sachse, 2014; Nielsen, 2015; Wyatt, 2016; Lowdermilk, 2016; James, 2016, etc.). However, it has not become an object of a special study in linguistics which makes it an area for further research.

In this paper I aim at complementing the researches mentioned above by specifying the names of the strategies and tactics of countermanipulation from the linguistic point of view and by using various types of Russian language discourse (TV debates, radio discussions, fiction, private telephone conversations) for indicating the linguistic characteristics of these strategies and tactics.

Verbal countermanipulation is a type of influence which is realized through speech and is response to manipulation; it aims to protect a communicator from the manipulator's control.

The term "countermanipulation" is used by a number of scientists (Nazare-Aga, 2004, Sheinov, 2014, Lowdermilk, 2016) though it is perceived differently. Sheinov (2014) calls countermanipulation the " 'opposite' manipulation" (Sheinov, 2014: 160). However, the Oxford dictionary says that the prefix "counter" has the meaning of "opposition to something" (English Oxford Living Dictionaries). The word "opposition" in its turn can be defined as "resistance or dissent, expressed in action or argument" (English Oxford Living Dictionaries). The first word in this definition, i.e. "resistance", has several meanings, including "the ability not to be affected by something, especially adversely" and "the refusal to accept or comply with something" (English Oxford Living Dictionaries). Therefore, countermanipulation 
does not imply using the same actions in return, but refusing to accept the manipulator's control and having the ability not to be affected by manipulation. This ability consists in detecting the fact of manipulation and implementing particular means to stay unaffected.

Verbal countermanipulation involves the use of individual strategies and tactics aimed at defending oneself against manipulation. The terms "overt strategy" and "covert strategy" presented in this paper partly agree with Sheinov's (2014) conception of the active and passive types of defence against manipulation.

The paper is organized into the following sections. In section 2 the data and methodology of the research are explained. Section 3 presents a short review of the terms "strategy" and "tactic" in the linguistic aspect and the data - the above mentioned strategies and tactics of verbal countermanipulation as they are used in various types of Russian language discourse - and their linguistic analysis. Conclusions are given in section 4. The Russian language examples of the strategies and tactics of countermanipulation are introduced in the appendix.

\section{Data and method}

Discourse analysis seeks to describe and explain linguistic phenomena in terms of the affective, cognitive, situational, and cultural contexts of their use and to identify linguistic resources through which we (re)construct our life (our identity, role, activity, community, emotion, stance, knowledge, belief, ideology, and so forth) (Weiyun He, 2003: 429).

Potter and Wetherell (1987) describe the two phases of analysis of discourse. The first phase is "the search for pattern in the data [...]: differences in either the content or form of accounts, and consistency: the identification of features shared by accounts" (Potter, Wetherell, 1987: 168). While searching for the felicitous examples for this research, first I had to check the context for the cases of manipulation (mainly dialogues). Then I checked these cases for the presence of verbal response to this manipulation. Basically, that constituted the first phase of my analysis.

The second phase is "the concern with function and consequences" (Potter, Wetherell, 1987: 168). After finding the response utterance in the dialogue with the manipulator my task was to define what function it performs in the text: whether it serves as (1) a verbal defense (or countermanipulation), (2) as an "opposite" manipulation or (3) simply yielding to manipulation. Here it is important to explain the difference between countermanipulation and so-called "opposite" manipulation. The "opposite" manipulation is the same manipulation but it is addressed back to the manipulator. The examples of the "opposite" manipulation are political debates with two or more participants using the manipulative strategies and tactics to change public opinion, discredit the opponents, etc. It resembles the verbal fight in which offence follows the other offence. But these are not the cases which I analyse and describe in this paper.

The next stage after selecting the countermanipulation cases was distinguishing their linguistic characteristics, with consideration of which I made an effort to organize them into the particular groups. For example, the peculiarity of broken record tactic is repetition of the same word, phrase or sentence with the same intonation (see paragraph 3.2.1).

I used various types of Russian language discourse to collect the data for this research: starting with political debates and TV talk shows and ending with fiction. The interesting fact is that, on one hand, I found more cases of effective implementation of the broken record tactic in the fiction rather than in the political debates and radio discussions and, on the other hand, I met more examples of successful usage of the tactic of revealing manipulation technique in political debates rather than in fiction. So in this paper I will look at and analyse various types of discourse to define the countermanipulative strategies and tactics and their linguistic characteristics. 


\section{Strategies and tactics of verbal countermanipulation}

Widely used mass manipulation influences the tendencies of language development, more specifically, many books are written on the topic of how to learn the science of manipulating the others (Powell, 2014; Hutton, Parris, 2015; Fisher, 2016; Fletcher, 2016 , etc.) In this regard, some linguists emphasize that nowadays it is highly important to develop the strategies of defence against manipulation because "language changes (or changes in language behaviour) can also trigger social changes" (Wodak, 1989: XV).

To defend oneself from the manipulation effect the communicator can use a number of countermanipulative strategies and tactics serving as the means for his/her defence.

The notion of a strategy is defined by linguists as "a property of a 'plan', that is, a (cognitive) representation of an action sequence that will be executed. It is that property of a plan that guarantees that the action sequence is carried out effectively and optimally, given the (known or assumed) circumstances of the action context" (van Dijk, 1984: 115). Consequently, the strategy includes a number of actions. They are aimed at reaching the certain communicative aim.

"The tactic must be considered as one or several verbal actions which promote the realization of a strategy" (Issers, 2008: 110). Thus the strategy may contain a number of tactics.

Some psychologists describe a number of strategies and tactics of countermanipulation (Braiker, 2004; Nazare-Aga, 2004; Sheinov, 2014; Edmüller, Wilhelm, 2006) using their own terms and names but without any sufficient explanation of why they chose this or that term or name.

Sometimes the names of the tactics are ill-considered. The name of the tactic "ignorieren und weitermachen" (ignore and continue) (Edmüller, Wilhelm, 2006: 33$34)$ does not correlate with its description. The authors say that the communicator should not yield to manipulation attempt and ignore the comments addressed to him/her, but then they add that within this tactic one can use pauses in conversation and constructive suggestions.

In other cases authors give different names to one and the same phenomenon. For example, the tactic of revealing manipulation technique is called "disabling the manipulation" (Braiker 2004) and "aus der Situation treten" (the way out) (Edmüller, Wilhelm, 2006: 39). Therefore there is no uniformity in the terminology of countermanipulation.

In this paper I make an effort to specify and explain the names of two strategies and four tactics of countermanipulation from the linguistic point of view.

\subsection{Overt resistance strategy}

The overt resistance strategy is frequently used in a public sphere (political TV shows and debates, radio discussions, etc). The aim of this strategy is to protect oneself from manipulator's control by using the direct ways of resistance to manipulation, when there is no need to save good relationships with a manipulator (if he/she is not a chief, special guest, etc.). The strategy involves the usage of particular tactics, two of which are proposed further in the text.

\subsubsection{Tactic of revealing manipulation technique}

The mechanism of this tactic lies in allowing manipulator to know that his/her manipulation has been disclosed. It is realized verbally by using words or phrases pointing to the attempt of manipulation. Two examples below illustrate this tactic. 
Example 1. The tactic is used by one of the participants $(A)$ of the Russian popular TV talk show ${ }^{1}$. The opponent $B$ uses a manipulative technique, ascribing to $A$ the words that he did not say (the manipulative aim is to discredit the opponent). $A$ points to the manipulation attempt three times. This repetition enhances the effect of countermanipulation, which effectively reveals the manipulative technique.

A: I am the last person to join Merkel's followers and multicultural policy.

After some time B asks A a question:

B: Nevertheless you represent the side of multiculturalism, as I see it. You agree with the fact that peacefully, let the migrants come to Europe, let's be friends all together. You know that when we had terroristic acts in Russia, we had a metro exploded in Moscow, none of the Europeans went and laid flowers to the Russian embassy [...]

A: You are now putting the words in my mouth, which are exactly the opposite to those that I said [...] I've said exactly the opposite! You are putting the words in my mouth, which not only I've never told, but exactly the opposite to those that I said (Poedinok: Barshevsky vs. Zhirinovsky. Ot 24.03.16 (HD)).

Example 2. The second example is taken from the radio discourse ${ }^{2}$. The interesting fact here is that the tactic is implemented in the form of a question:

A: Those corruptionists and swindlers, who stay in Edinaya Rossiya, pay no penalty. Let's see who was the closest associate of Luzhkov? Mr. Resin with his famous onemillion dollar watch, who recently joined the party!

B: Aleksey, wait a bit, look, by the examples of Luzhkov, Resin [...] Well, with reference to two people, yes, can we accuse the whole party, that this is the party of thieves and corruptionists? [...] all these people are with a prefix of "former", except for Gryzlov? (Sukhoi ostatok: Navalny vs Fedorov (EdRo) 21 fevralya 2011 g.).

\subsubsection{Flat refusal tactic}

Longman dictionary defines flat refusal is "a refusal etc. that is definite and which someone will not change" (Longman Dictionary. English version). This tactic is used both in public and private spheres. The aim is to show the manipulator that his/her control is completely denied by his/her conversation partner. Its linguistic characteristics are the negative particle "not" and the lexeme "no" in the function of a determiner and exclamation.

Example 1. Flat refusal tactic is demonstrated during the TV debates ${ }^{3}$ where $B$ acts on the defensive.

${ }^{1}$ The talk show "Poedinok" - the debates between Vladimir Volfovich Zhirinovsky and Mikhail Yurevich Barshchevsky (A) are devoted to the problem of the influence of terroristic acts in Belgium on the European security policy, migration policy and restriction of rights and freedoms of the European Union citizens. The expert from the side of Zhirinovsky - Vasily Vlasov (B) - takes part in a discussion.

${ }^{2}$ The radio programme "Sukhoi ostatok" (Radio Finam FM) - discussion between Alexey Anatolievich Navalny (A) and Evgeniy Alekseevich Fedorov. Navalny claims that the party Edinaya Rossia gives political cronies to the corruptionists, citing Yuri Mikhailovich Luzhkov and Vladimir Iosifovich Resin as examples which can be treated as a manipulative technique of shifting the negative assessment from several people to the whole party Edinaya Rossia. The host of the radio programme Yuri Pronko (B) reveals the Speaker's 1 wrong generalization.

${ }^{3}$ TV talk show "Pryamoi razgovor" (Plain talk) - the debates between Aleksey Anatolievich Navalny (A) and Anatoly Borisovich Chubais (B). A accuses "Rusnano" and its CEO (B) of undue application of the public money. A wants B to come back to 
A: Anatoliy Chubais as a man interested in the development of science and education should come and say to the public: "Stop that! I don't want to listen to this rubbish anymore! I don't want this nonsense happen again! I want a healthy growth for my country!"

B: You want to draw me into the political field, and I will not go there [...] I have been in the political field for 25 years, and there, where you are going, Aleksey Anatolievich, I am from there [...] but I am not interested in it, I do not want to do it (Debati. Navalny vs Chubais. Polnaya versia).

Example 2. One more example from the same TV debates (see Example 1). The implemented tactic explains the reason for $B$ 's refusal and justifies $B$ 's point of view.

A: Is Navalny's investigation of state corporations' corruption important for the society? Will you take to the streets to support Navalny, if in the end he is put into prison? ${ }^{4}$

B: No! No! [...] I will not change my position at all [...] The fact is that, as it happened, I took to the streets [...] I just think that everyone must be responsible for the business he took on [...] Today business, particularly with public money, and politics are not held together around here [...] I must choose one of two [...] Then I think that I have a right to boldly and impudently choose the kind of occupation that I like and I am interested in! (Debati. Navalny vs Chubais. Polnaya versia).

Example 3. Another example is taken from the fiction discourse ${ }^{5}$.

A: Has the honoured merchant already paid for the moorage?

B: No, but $[\ldots]$

A: That settles the matter. Wait for one of the moorings get free. Or go to the other wharf.

B: I am a big man in Abudag!

A: Maybe, but here is not Abudag. That's that (Afanasyev, 2012: 20).

Example 4. The tactic is used in the telephone conversation ${ }^{6} . A$ wants to entice $B$ to buy their medical service products.

A: Good afternoon! Can I speak to Anna?

B: Anna is speaking.

the political sphere, use his political prestige and advocate for fair election and science development in Russia. A manipulates the viewers that B was much more successful and authoritative in political sphere rather than in business sphere (the strategy of discrediting B as a chairman of "Rusnano" ).

4 The viewer of the talk show "Pryamoi razgovor" Elena Vasilyeva (A) asks a manipulative question addressed to Chubais (B). If Chubais answers "no" then it automatically means that he does not think Navalny's investigation of state corporations' corruption is important for the society. That fact discredits his personal interest in fighting corruption in Russia.

5 "Igra vslepuyu" (Blind play) by Valery Afanasyev. A merchant (B) from Abudag (city) with his ship's company approaches the other city's wharf and wants to moor to it though all the free places are occupied by other vessels. He sees the opportunity to remove one of the ships which is being unloaded. Two merchants start to argue for the mooring place. Vik (A) buts into their conversation and addresses to the merchant who wants to get the place for his ship. The merchant uses manipulation mentioning his high standing in his own city Abudag.

${ }^{6}$ The example is taken from my own experience. The names are changed due to the privacy policy.

XLinguae, Volume 11, Issue 3, June 2018, ISSN 1337-8384, eISSN 2453-711X 
A: Anna, I'm a specialist of a X medical clinic. Now we are having a special offering for you. You can be medically examined by any specialist in our clinic for free! Will you tell me your age and I will inform you to which specialist you can be sent?

B: You see, now I have no need to be medically examined, so I think there's no point in telling you my age.

A: But this is a really unique offering! If you can't come yourself, can you tell me who from your friends or relatives can be given such a present?

B: Thank you for your care, but I really think that my friends and relatives can take care of themselves on their own.

A: I got it. Thank you!

\subsection{Covert resistance strategy}

Covert resistance is veiled so that the manipulator cannot at once understand that his/her conversation partner opposes his/her manipulation. So it can take longer to make the manipulator leave his/her manipulative attempt to get something from you. As a rule, covert resistance strategy does not seem to be so categorical and flat, due to the need to stay in good relationships with the manipulator. The covert resistance tactics are more inventive and tortuous so they can take more time and effort as they often need to be repeated several times to get the effect.

\subsubsection{Broken record tactic}

The mechanism of this tactic has been described by a number of scientists, viz. Braiker (2004), Nazare-Aga (2004), Edmüller, Wilhelm (2006), etc. By repeating the same word, phrase or sentence with the same intonation the communicator counteracts and neutralizes the manipulator's efforts to get the benefit from him / her.

Example 1. The talk between Nozdrev and Chichikov from "Dead souls" by Nikolai Vasil'evich Gogol'. Nozdrev tries to reveal Chichikov's manipulative aim (to sell the dead souls at a good price) using the broken record tactic.

Nozdrev: Of what use would they be to you?

Chichikov: Never mind. I have a purpose in wanting them.

Nozdrev: What purpose?

Chichikov: A purpose which is strictly my own affair. In short, I need them.

Nozdrev: You seem to have hatched a very fine scheme. Out with it, now! What is in the wind?

Chichikov: How could I have hatched such a scheme as you say? One could not very well hatch a scheme out of such a trifle as this.

Nozdrev: Then for what purpose do you want the serfs? (Gogol, 1916: 77)

In the end Chichikov has to say the purpose though made up on the spot - as if he wants to get married, but the bride's parents demand that he possesses not less than three hundred souls, so he needs to get them. Still the tactic implemented by Nozdrev is effective as it makes the manipulator refuse of his manipulation technique (get the souls without telling the purpose).

Example 2. The dialogue is taken from the Russian fiction $\operatorname{book}^{8}$. To convince $B$ to play the role and to come to the shooting location $A$ uses broken record tactic and

\footnotetext{
${ }^{7}$ Translated by D. J. Hogarth. Chichikov comes to Nozdrev's house. In the beginning of their conversation he exacts a promise from Nozdrev to satisfy his request under any circumstances. Chichikov asks Nozdrev to sell him his dead souls without saying why he needs them.

8"Pushki privezli" (Cannons are delivered) by Yuri Vyazemsky. Kirill (B) lands a role which he hates because it has a "dull and idiotic" text. However he cannot refuse it as 
short and exact arguments without any response aggression. $A$ also implements clarification tactic (see paragraph 3.2.2) which consists in the clearing up the manipulator's aim (Kirill, why are you lying to me?). In the end $B$ agrees to come to the shooting location.

\section{A: Kirill, we need you so much $[\ldots]$ \\ B: When?}

A: Tomorrow morning. In Yelizovo.

B: What?! Tomorrow morning?! In Yelizovo?! [...] No, it's impossible! It's absolutely impossible! I have a shooting in "Mosfilm".

\section{A: Kirill, we need you so much $[\ldots]$}

B: What the hell! [...] I'm telling you: tomorrow I'm busy. I've got a shooting in "Stolen gold".

A: Kirill, why are you lying to me? [...] You are not busy in "Stolen gold" tomorrow. I checked it out. They told me you are free [...]

B: Then when should I depart?

A: Today in the evening (Vyazemsky, 2010: 19-20).

\subsubsection{Clarification tactic}

The aim of this tactic is to get more information from the manipulator about his/her intentions. The usual form of the tactic is a question. The example from fiction ${ }^{9}$ is illustrated below.

$B$ uses such manipulative tactics as deceit (The gold is flowing to the duke's treasury) and generalization (I shouldn't wonder if his treasury will soon become bigger than the emperor's one). By using the clarification tactic $A$ asks $B$ to specify his arguments (Can you tell me the names? And what measures seem to be urgent to you?). In the end $B$ refers to the lack of information (This is not so clear, I don't have the facts).

A: And what's wrong about the duke? [...]

B: His influence is increasing, and this fact cannot but worry me, the true homager of His Imperial Majesty. The gold is flowing to the duke's treasury. I shouldn't wonder if his treasury will soon become bigger than the emperor's one. [...] Some dukedom noblemen chant the praises to their overlord, but the others repine.

A: Repine? How so? [...] Can you tell me the names?

B: This is not so clear, His Imperial Majesty. [...] The peace of the empire is a very fragile thing, it's easy to shake. Sir, you should immediately take measures.

A: Do you think so? And what measures seem to be urgent to you?

B: The measures which will allow us to restrict the influence of duke Fagua and some of his supporters [...]

A: I'm glad that you are guarding the interests of the empire. But if you could tell me something more concrete...

B: Alas, Sir, I don't have the facts (Afanasyev, 2012: 96).

\section{CONCLUSIONS}

the director counts upon him. Assistant director Serafima (A) calls Kirill to inform him about the film shoot. Kirill manipulates her feelings hoping that they take somebody else for this role. He also finds excuses in his being busy.

9"Igra vslepuyu" (Blind play) by Valery Afanasyev. By asking elaborative questions the emperor (A) manages to make count Oster (B) give up his manipulative plan which is to convince A to shift duke Fagua from his territories and send him to the very dangerous mission from where he cannot come back so that B can take the duke's territories later. 
In this paper, I have analyzed two strategies (overt and covert) and four tactics of countermanipulation with the help of discourse analysis. The overt strategy is aimed at protecting oneself from manipulator's influence by using direct ways of resistance to manipulation. Within this strategy I described two tactics - (1) tactic of revealing manipulation technique, which is realized verbally by using words or phrases pointing to the attempt of manipulation in the form of a statement or a question, and (2) flat refusal tactic, the linguistic characteristic of which is the negative particle "not" and the lexeme "no" which can function as a determiner or as an exclamation. The covert strategy is veiled so that it is not clear for the manipulator that his communicator opposes his/her control. The means of this strategy are not so categorical and flat as the previous strategy's ones. Two of the tactics which can be used under this strategy are (1) broken record tactic - the condition of its effective implementation is repetition of the same word, phrase or sentence with the same intonation - and (2) clarification tactic which is usually used in the form of a question to get more information from the manipulator about what his/her intentions are. The list of countermanipulative strategies and tactics remains open for enlarging.

The strategies and tactics of countermanipulation need to be further examined on a deeper lexical and syntactic level with the analysis of a larger number of examples from various types of discourse.

\section{Appendix}

The examples in Russian language

\section{Tactic of revealing manipulation technique}

(1) The talk show "Poedinok" - the talk between Vasily Vlasov (B) and Mikhail Yur'evich Barshchevsky (A).

A: Я являюсь последним человеком, который может себя отнести к поклонникам Меркель и мультикультурной политики.

Позже В задает вопрос $\mathbf{A .}$

В: Вы все-таки представляете сторону мультикультурализма, как я понимаю. Вы согласны с тем, что спокойно, пусть мигранты приезжают в Европу, давайте все вместе дружить. Вы знаете, что когда у нас в России происходили теракты, у нас в Москве взрывали метро, ни один европеец не пошел и не возложил цветы к российскому посольству.

А: Вы сейчас приписываете мне слова, которые ровно обратные тому, что я говорил. [...] Ровно обратное сказал! Вы мне приписываете слова, не просто, которые я не говорил, а обратные тем, которые я произносил.

(2) The radio programme "Sukhoi ostatok" (Radio Finam FM) - discussion between Alexey Anatol'evich Navalny (A) and Yuri Pronko (B).

А: Те коррупционеры и жулики, которые остаются в Единой России никакого наказания не несут. Давайте посмотрим, а кто же был ближайшим соратником Лужкова? Господин Ресин, который вступил в Единую Россию совсем недавно со своими знаменитыми часами за один миллион долларов!

B: Алексей, подождите, ну а смотрите, на примерах Лужкова, Ресина. [...] Ну, на основании двух людей, да, можно ли всю партию обвинять, что это партия воров и коррупционеров? [...] но это все люди с приставкой «бывший», кроме Грызлова?

\section{Flat refusal tactic}


(1) TV talk show "Pryamoi razgovor" (Plain talk) - the debates between Aleksey Anatol'evich Navalny (A) and Anatoly Borisovich Chubais (B).

A: Анатолий Чубайс как человек который заинтересован в развитии науки и образования должен выйти и сказать: «Хватит! Я не хочу больше дрянь эту слышать! Я хочу чтобы вот эта чушь не повторялась! Хочу чтобы страна нормально развивалась!»

В: Вы меня хотите вытащить в политическое поле, а я не пойду! [...] Я в политическом поле 25 лет. Вот туда, куда вы идете, Алексей Анатольевич, я оттуда $[\ldots]$ только мне это не интересно, я не хочу этим заниматься.

(2) TV talk show "Pryamoi razgovor" (Plain talk) - the debates between Aleksey Anatolievich Navalny and Anatoly Borisovich Chubais (B). The viewer of the talk show "Pryamoi razgovor" Elena Vasilyeva (A) asks a question.

A: Расследования Навального о неэффективности и коррупции в госкорпорациях - это важно для общества? И если за это его в итоге посадят выйдете ли за него на улицы?

В: Нет! Нет! [...] Я точно не изменю свою позицию. [...] Я, вообще говоря, так случилось, что выходил как-то на улицу. [...] Я просто считаю, что каждый должен отвечать за дело, за которое взялся. [...] У нас сегодня бизнес, тем более с государственными деньгами, и политику - не совмещают. [...] Я должен выбрать одно из двух. [...] Дальше, я считаю, нагло и нахально, я имею право выбрать тот вид деятельности, который мне нравится и мне интересен!

(3) "Igra vslepuyu" (Blind play) by Valery Afanasyev. The talk between Vik (A) and the merchant $(\mathrm{B})$.

A: Уважаемый купец уже заплатил за стоянку?

B: Нет, но... [...]

A: Вопрос исчерпан. Ждите, когда один из причалов освободится. Или идите к другой пристани.

В: Я важный человек в Абудаге!

А: Может быть, но здесь не Абудаг. Я все сказал.

(4) A telephone conversation.

А: Добрый день, можно мне поговорить с Анной?

B: Да, это я.

A: Анна, вас беспокоит специалист клиники X. У нас сейчас действует уникальное предложение, вы можете пройти осмотр у любого специалиста бесплатно! Скажите свой возраст и я сориентирую вас, к какому специалисту вас можно будет направить.

В: Вы знаете, мне сейчас не нужно посещать никаких врачей, поэтому, думаю, что и возраст мой вам сообщать незачем.

A: Но это же такая уникальная акция! Если вы не можете прийти сами, то хотя бы посоветуйте друзей или родственников, кому можно будет сделать такой подарок?

B: Спасибо за заботу, но я правда думаю, что мои знакомые сами о себе позаботятся.

А: Я вас услышала. Спасибо!

\section{Broken record tactic}

XLinguae, Volume 11, Issue 3, June 2018, ISSN 1337-8384, eISSN 2453-711X 
(1) “Dead souls" by Nikolai Vasil'evich Gogol.

Nozdrev: А на что тебе?

Chichikov: Ну да мне нужно.

Nozdrev: Да на что?

Chichikov: Ну да уж нужно... уж это мое дело, - словом, нужно.

Nozdrev: Ну уж, верно, что-нибудь затеял. Признайся, что?

Chichikov: Да что ж затеял? из этакого пустяка и затеять ничего нельзя.

Nozdrev: Да зачем же они тебе? (Gogol, 1957: 108)

(2) "Pushki privezli" (Cannons are delivered) by Yuri Vyazemsky. The telephone conversation between Serafima (A) and Kirill (B).

\section{А: Кирилл, вы нам очень нужны.}

В: Когда?

А: Завтра утром. В Елизово.

В: Что?! Завтра утром?! В Елизово?! [...] Нет, это невозможно! Это абсолютно невозможно! У меня съемки на «Мосфильме».

А: Кирилл, вы нам очень нужны [...]

B: Что за черт? [...] Да я вам русским языком говорю: я завтра занят! У меня съемки в «Похищенном золоте».

А: Кирилл, зачем вы меня обманываете? [...] Вы завтра не заняты в «Похищенном золоте». Я проверяла. Мне сказали, что вы свободны [...]

В: Когда выезжать-то?

A: Сегодня вечером.

\section{Clarification tactic}

(1) "Igra vslepuyu" (Blind play) by Valery Afanasyev. The talk between the emperor (A) and count Oster (B).

A: А что герцог?

В: Его влияние усиливается, и это не может не беспокоить меня, как верного подданного вашего императорского величества. Золото буквально рекой течет в казну Фагуа. Не удивлюсь, если скоро его казна станет больше императорской. [...] Одни дворяне герцогства воздают хвалу своему сюзерену, но другие ропщут.

А: Как «ропщут»? [...] Можешь назвать имена?

В: Это не так явно, ваше императорское величество. [...] Спокойствие империи - слишком хрупкая вещь, поколебать его несложно. Сир, вы должны принять незамедлительные меры.

\section{А: Ты думаешь? И какие меры кажутся тебе необходимыми?}

B: Меры, которые позволили бы ограничить влияние герцога и некоторых его сторонников [...]

А: Я рад, что ты стоишь на страже интересов империи. Но если бы ты мог сказать что-то более конкретное...

В: Увы, сир, я не располагаю фактами.

\section{Bibliographic references}

AFANASYEV, V. 2012. Igra vslepuyu. Moscow: Alfa-kniga. ISBN 978-5-99221326-3

BARNHILL, A. 2014. What is manipulation? In: Manipulation: theory and practice. New York: Oxford University Press, pp. 51-73. ISBN 978-0-19-933821-4 
BRAIKER, H. 2004. Who's Pulling Your Strings?: How to Break the Cycle of Manipulation and Regain Control of Your Life. New York: The McGraw-Hill Companies. ISBN 0-07-143568-9

BUSS, D. 1992. Manipulation in close relationships: five personality factors in interactional context. In: Journal of Personality and Social Psychology, v. 60, n. 2, 477-499. DOI: 10.1111/j.1467-6494.1992.tb00981.x

Debati. Navalny vs Chubais. Polnaya versia. [online] Available online: http://www.youtube.com/watch? $\mathrm{v}=$ nsoIcQYlPxg\&t=1985s (accessed data: 11/05/2017).

van DIJK, T. 1984. Prejudice in discourse. An Analysis of Ethnic Prejudice in Cognition and Conversation. John Benjamins publishing company Amsterdam/Philadelphia. ISBN 0-915027-43-7

EDMULLER, A. et al. 2012. Manipulationen abwehren. Munich: Haufe. ISBN 3648028634

EDMÜLLER, A. - WILHELM, T. 2006. Manipulationstechniken. Munich: Haufe. ISBN 3448049638

English Oxford Living Dictionaries. [online] URL: https://en.oxforddictionaries.com (accessed data: 23/06/2017).

FISHER, S. 2016. Manipulation: How To Get Others To Do What You Want. North Charleston: CreateSpace Independent Publishing Platform. ISBN 1530905265

FLETCHER, D. 2016. Manipulate Anyone: 175 Awesome Brain Hacks, Tricks \& Techniques. Denver: DF Chase Publishing Group.

GOGOL, N. 1916. Dead souls. Transl. D. J. Hogarth. London \& Toronto: J.M. Dent \& Sons Ltd. New York: E.P. Dutton \& Co.

GOGOL, N. 1957. Mertvye dushi. Moscow: Detgiz.

GOODIN, R. 1980. Manipulatory politics. New Haven: Yale University Press. DOI $10.1086 / 292422$

HUTTON, R. - PARRIS, M. 2015. Would They Lie to You?: How to Spin Friends and Manipulate People. London: Elliott \& Thompson. ISBN 1783960086

ISSERS, O. 2008. Kommunikativniye strategii i taktiki russkoi rechi. Moscow: LKI. ISBN 978-5-382-00698-7

JAMES, R. 2016. Manipulation: The Definitive Guide to Understanding Manipulation, Mind Control and NLP. North Charleston: CreateSpace Independent Publishing Platform. ISBN 1541292839

KOPNINA, G. 2008. Rechevoye manipulirovanie. Moscow: Flinta, Nauka. ISBN 978-5-9765-0060-0

LENTZ, J. 1989. Effective handling of manipulating persons. Springfield: Charles C Thomas Pub Ltd. ISBN 0398055556

Longman Dictionary. English version. [online] Available online: http://www.ldoceonline.com (accessed data: 23/06/2017).

LOWDERMILK, E. 2016. Two Can Play That Game: Manipulation, CounterManipulation, and Recognition in John 21 through the Eyes of Genesis. Eugene: Pickwick Publications. ISBN 1498208460

MENZ, F. 1989. Manipulation strategies in newspapers: a program for critical linguistics. In: Language, power and ideology. Studies in Political Discourse. John Benjamins publishing company Amsterdam/Philadelphia, pp. 227-251. ISBN 90272 24161

NAZARE-AGA, I. 2004. Les manipulateurs sont parmi nous: Qui sont-ils? Comment s'en proteger? Québec: Les Editions de l'Homme. ISBN 2761919718

NIELSEN, S. 2015. Manipulation: How to Recognize and Outwit Emotional Manipulation and Mind Control in Your Relationships. North Charleston: CreateSpace Independent Publishing Platform. ISBN 1512050156

XLinguae, Volume 11, Issue 3, June 2018, ISSN 1337-8384, eISSN 2453-711X 
POTTER, J. - WETHERELL, M. 1987. Discourse and social psychology. Beyond attitudes and behaviour. London: Sage Publications. ISBN 0-8039-8055-8

POWELL, J. 2014. Mind Control Mastery: Successful Guide to Human Psychology and Manipulation, Persuasion and Deception. North Charleston: CreateSpace Independent Publishing Platform. ISBN 1500263885

Poedinok: Barshevsky vs. Zhirinovsky. Ot 24.03.16 (HD). [online] Available online: https://www.youtube.com/watch? $\mathrm{v}=\mathrm{Ou} 8 \mathrm{JjJ} J \mathrm{HTYM} \& \mathrm{t}=4183 \mathrm{~s}$ (accessed data: 20/06/2017).

ROBERTS, C. 2006. Context in Dynamic Interpretation. In: The Handbook of Pragmatics. Padstow: Blackwell Publishing, pp. 197-221. ISBN: 978-0-631-22548-5

SACHSE, R. 2014. Manipulation und Selbsttäuschung. Berlin: Springer. ISBN 978-3642-54823-9

SHEINOV, V. 2014. Manipulirovanie i zashita ot manipulyatsii. St. Petersburg: Piter. ISBN 978-5-496-00472-5

SIMON, G. 2010. In Sheep's Clothing: Understanding and Dealing with Manipulative People. Little Rock: Parkhurst Brothers Publishers Inc. ISBN 1935166301

Sukhoi ostatok: Navalny vs Fedorov (EdRo) 21 fevralya 2011 g. [online] Available online: https://www.youtube.com/watch? $\mathrm{v}=$ muePjswz6VM (accessed data: 26/05/2017).

VYAZEMSKY, Y. 2010. Bestoloch. Moscow: Astrel: AST. ISBN: 978-5-17-0646067

WEIYUN HE, A. 2003. Discourse Analysis. In: The Handbook of Linguistics. Oxford: Blackwell Publishers, pp. 428-445. ISBN 0-631-20497-0

WODAK, R. 1989. Introduction to Language, power and ideology. Studies in political discourse. John Benjamins publishing company Amsterdam/Philadelphia, pp. XIVXX. ISBN 9027224161

WYATT, H. 2016. Defeat Manipulation 101: The Secret Handbook To Defend Yourself Against Those Who Attempt To Manipulate You. North Charleston: CreateSpace Independent Publishing Platform. ISBN 1539187780

Words: 5730

Characters: 36298 (20,16 standard pages)

Senior lecturer Marina Viktorovna Petrova

School of Philology and Language Communication

Siberian Federal University

82a Prospekt Svobodniy

660041 Krasnoyarsk

Russia

marina.kondoba@mail.ru 